\title{
ТЕМПЕРАТУРНИЙ РЕЖИМ ГРУНТОВИХ МАСИВІВ ЯК ГЕОЛОГІЧНИЙ ВПЛИВ НА ОСНОВИ БУДІВЕЛЬ
}

\section{TEMPERATURE REGIME OF SOIL MASSIVES AS A GEOLOGICAL INFLUENCE ON THE FOUNDING OF BUILDINGS}

Пашинський В.А., д.т.н., проф., Пашинський М.В., к.т.н., Карпушин С.О., к.т.н., доц., (Центральноукраїнський національний технічний університет, м. Кропивницький)

\section{Pashynskyi V.A., Sc.D., prof, Pashynskyi M.V., PhD, Karpushyn S.O., PhD, associate professor (Central Ukrainian National Technical University, Kropyvnytskyi)}

Проаналізовані результати спостережень за температурою трунту на 11 метеостаниіях України. Розроблена методика визначення мінімальних та максимальних розрахункових значень температури трунту. Визначені розрахункові значення температури трунту для глибин до 3,2 м, проаналізовані та описані їх залежності від глибини й періоду повторюваності. Результати дослідження можуть бути використані в теплотехнічних розрахунках підземних частин будівельних об'єктів.

The study was performed in order to develop a method for determining the calculated values of the temperature of soil massives of the buildings foundations based on the results of meteorological observations, as well as analysis of their changes in depth and territory. For the analysis the generalized results of measurements of soil temperature on depth up to $3.2 \mathrm{~m}$, which were carried out by deep thermometers at 11 meteorological stations from different areas of Ukraine are used.

It is established that with increasing depth, seasonal changes in soil temperature attenuate and lag behind in time from changes in air temperature and soil surface. Standard deviations of soil temperature do not have a pronounced seasonal variability, but systematically decrease with increasing depth.

The probabilistic method of determining the design values of soil temperature is developed on the basis of the description of average minima and average maxima of temperature in the form of sequences of normally distributed random variables corresponding to 12 months of the year. According to the data of 11 selected meteorological stations of Ukraine, the minimum and maximum design values of soil temperature for depths up to $3.2 \mathrm{~m}$ and return periods of $20 \ldots 200$ years have been determined. Insignificant dependence on the return periods allowed to take as calculated data the value of soil temperature, which correspond to a return period of 100 years.

Dependences of minimum and maximum design values of soil temperature on depth for 11 meteorological stations of Ukraine are described by analytical expressions of exponential type. By analyzing these expressions, it was found that at a depth of $8 \ldots 13 \mathrm{~m}$, the minimum and maximum design values of soil temperature approach $+12 \ldots+18^{\circ} \mathrm{C}$ and remain unchanged throughout the year. 
The obtained results allow to predict the probable limits of soil temperature change at different depths and can be used when performing thermal calculations of deep rooms and when assessing the force effect of temperature on underground structures. глибини.

Ключові слова: температура трунту, розрахункові значення, залежності від

Keywords: soil temperature, design values, depth dependence.

Постановка проблеми. Температура експлуатаційного середовища істотно впливає на будівлі, споруди та будівельні конструкції. Зокрема, зміни температури грунтового масиву, який служить основою будівлі, впливають на умови експлуатації будівельних матеріалів і температурний режим заглиблених приміщень, а також можуть викликати силові впливи на несучі конструкції. Для урахування цих впливів при проектуванні будівель необхідно проаналізувати наявні результати спостережень за температурою грунту на метеостанціях 3 різних кліматичних зон, здійснити їх імовірнісний опис, виявити закономірності зміни по глибині й по території України та встановити розрахункові значення температури грунту на різних глибинах.

Аналіз відомих досліджень і публікацій. Достатньо дослідженим кліматичним явищем є температура атмосферного повітря, вплив якої на будівлі та споруди відображений розрахунковими параметрами, наведеними в нормах проектування [1, 2]. В нормах [3] та в монографії [4] показано, що не менш важливим є вплив температури грунту на підземні частини будівель і споруд.

Температура грунту, як i температура повітря, систематично вимірюється на метеостанціях України. Методика цих вимірювань на глибинах до 3,2 м регламентована настановою [5]. Узагальнені результати вимірювань опубліковані в довіднику [6], де для 210 метеостанцій України та кожного 3 місяців року наведені статистичні характеристики таких показників: середнє значення, середній мінімум та середній максимум температури повітря; середнє значення, середній мінімум та середній максимум температури від поверхні грунту до глибини 3,2 м.

Закономірності зміни температури грунту протягом року та за глибиною аналізувалися в численних дослідженнях, результати яких опубліковані в наукових працях та увійшли до довідкової та навчальної літератури. Наприклад, в [7] показано, що сезонні коливання температури грунту на усіх глибинах відбуваються з періодом в один рік, але амплітуда цих коливань зменшується 3 глибиною за експоненціальним законом. Добові коливання температури грунту затухають на глибині $0,7 \ldots 1,0$ м.

Досить детальний аналіз закономірностей зміни середньомісячних температур грунту на глибинах зроблений у статті [8]. За результатами аналізу даних 14 метеостанцій України виявлені особливості сезонних змін 
температури грунту на різних глибинах, залежності температури від глибини, а також проаналізовані зміни в часі протягом 1996...2015 років. В роботах $[7,8]$ також вказано, що закономірності зміни температури значною мірою залежать від фізичних і теплових характеристик грунту.

Попри досить добре вивчені та опубліковані загальні закономірності зміни температури грунтових масивів, наукові публікації та нормативні документи $[1,2]$ не містять розрахункових значень температури грунту, потрібних для проектування несучих та огороджувальних конструкцій підземних частин будівель і споруд. Розрахункові значення температури грунту слід встановити аналогічно розрахунковим значенням інших кліматичних навантажень і впливів $[1,2]$ методами теорії надійності, які враховують випадкову мінливість температур грунту.

Мета дослідження полягає в розробленні методики визначення розрахункових значень температури грунтових масивів основ будівельних об'єктів за результатами метеорологічних спостережень, а також в аналізі їх змін за глибиною й по території.

Вихідні дані та їх попередній аналіз. Для аналізу температури грунту на різних глибинах сформована вибіркова мережа метеостанцій, показана на рис. 1. Вибрані 11 метеостанцій розміщені в різних регіонах і відображають характер зміни температури грунту по території України.

За довідником [1] сформована база даних, яка для кожної з обраних метеостанцій містить статистичні характеристики температури повітря, температури поверхні та температури грунту на глибині $0,2 \mathrm{M}, 0,4 \mathrm{~m}, 0,8 \mathrm{м}$, 1,2 м, 1,6 м, 2,4 м і 3,2 м. Для кожного з місяців року наведені середні значення та стандарти:

- середньомісячної температури $M$ і $S$;

- середнього мінімуму температури $M_{\min }$ i $S_{\min }$;

- середнього максимуму температури $M_{\max }$ i $S_{\max }$.

Попередній аналіз метеорологічних даних виконано на прикладі середньомісячних температур грунту та їх стандартів на метеостанції м. Ново-Миргород Кіровоградської області. На рис. 2 зображено річний хід середньомісячних температур грунту та їх стандартів на поверхні та на глибинах 0,2 м, 0,8 м, 1,6 м і 3,2 м. На поверхні грунту, як і в повітрі, мінімальна температура спостерігається в січні-лютому, а максимальна - в липні. 3 ростом глибини амплітуда річних змін стає меншою, а річний хід температури відстає від змін температури повітря й поверхні грунту. Наприклад, на глибині 3,2 м мінімальна температура реалізується в квітні, а максимальна - в жовтні. Отже, за рахунок повільної теплопередачі через товщу грунту сезонні коливання температури 3 глибиною затухають $\mathrm{i}$ відстають в часі від змін температури повітря й поверхні грунту. Аналогічні висновки зроблені в статті [8] за результатами аналізу даних метеостанцій України. 


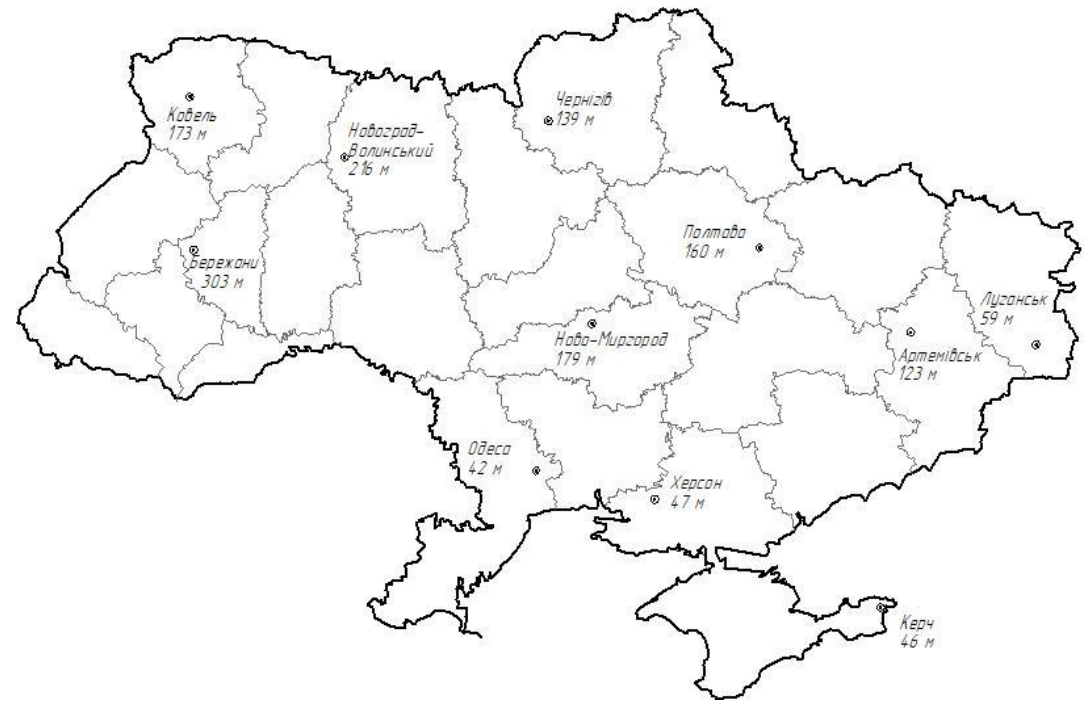

Рис. 1. Вибіркова мережа метеостанцій України
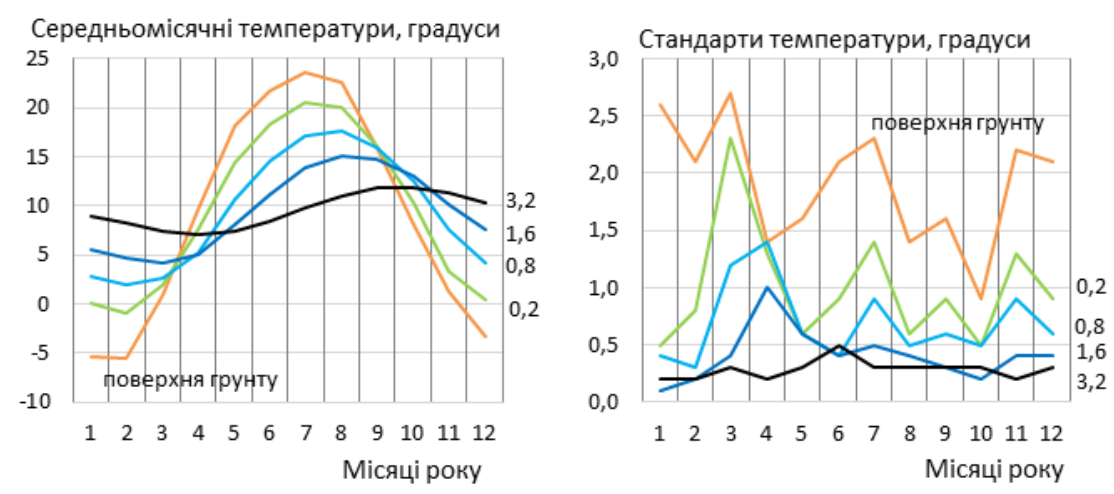

Рис. 2. Річний хід середньомісячних значень та стандартів температури грунту на поверхні та на глибинах 0,2 м, 0,8 м, 1,6 м, 3,2 м за даними метеостанції м. Ново-Миргород

Наведений на рис. 2 графік річного ходу стандартів середньомісячної температури грунту на тих же глибинах вказує на відсутність виражених сезонних змін. Протягом року стандарти змінюються досить хаотично, але систематично зменшуються 3 глибиною, що підтверджує затухання коливань температури грунту на глибині. 
Зміни температури по глибині відображені на рисунку 3 для чотирьох місяців, що відображають сезони року: зиму, весну, літо та осінь. Висока температура поверхні грунту в липні падає 3 глибиною, а низька температура поверхні грунту в січні з глибиною росте, наближаючись до липневої температури. В жовтні поверхня грунту холодна, а в глибині ще зберігається літнє тепло. У квітні поверхня грунту вже прогрівається, а в глибині ще досить холодно. Загалом сезонна мінливість температури грунту стабілізуються 3 ростом глибини, у результаті чого на значній глибині грунт практично не підлягає впливу сезонних коливань метеорологічних факторів і має постійну температуру, яка асимптотично наближається приблизно до $+10^{\circ} \mathrm{C}$. Подібні закономірності виявлені також в раніше згаданій роботі [8].
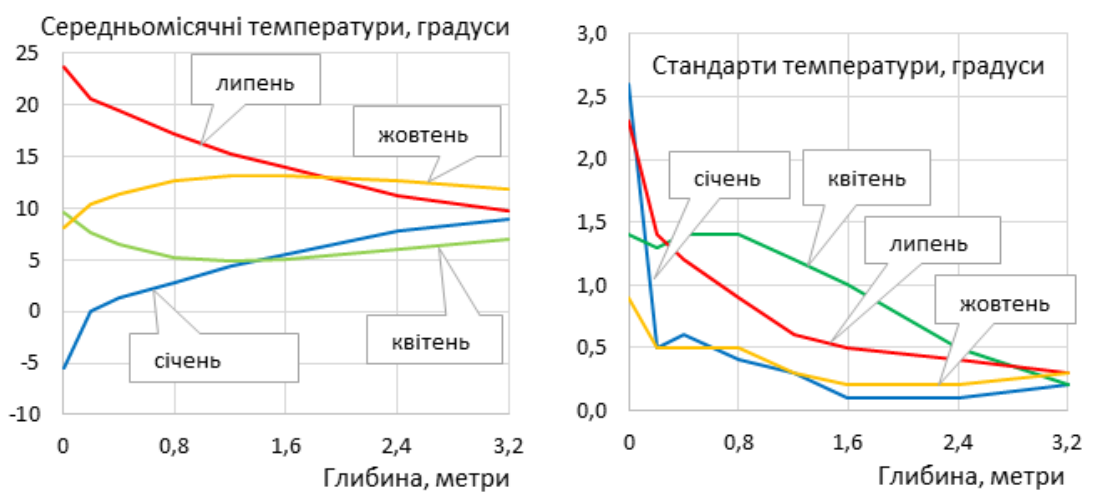

Рис. 3. Зміни середньомісячних значень та стандартів температури грунту по глибині за даними метеостанції м. Ново-Миргород

3 рис. 3 також видно, що з ростом глибини стандарти зменшуються, вирівнюються для усіх сезонів року та асимптотично наближаються до нуля. У січні та в липні спостерігаються значні перепади між стандартами температури поверхні грунту та температури на глибині 0,2 м. Більша мінливість температур на поверхні грунту пояснюється безпосереднім контактом з повітрям та додатковим нагріванням від дії сонячної радіації.

Попередній аналіз даних інших метеостанцій вказує на аналогічні закономірності зміни температури грунту залежно від глибини і пори року. При цьому спостерігається помітні зміни температури повітря й поверхні грунту по території України.

Методика обчислення розрахункових значень температури грунту. По аналогії з іншими кліматичними навантаженнями та впливами $[2,4]$, розрахунковими будемо вважати мінімальні $X_{\min }$ та максимальні $X_{\max }$ 
значення температури грунту, вихід за які може спостерігатися протягом однісї доби за встановлений строк служби конструкції чи період повторюваності $T$. Наявні дані дозволяють представити мінімальні та максимальні температури повітря у формі послідовностей 3 12-ти нормально розподілених випадкових величин. Виходячи 3 такого імовірнісного подання, тривалість перебування температури нижче мінімального розрахункового значення $X_{\min }$ на протязі строку служби $T_{\min }$ обчислюється за формулою

$$
T_{\min }=30,5 \times T \times \sum_{i=1}^{12} F\left(X_{\min }, M_{\mathrm{i}, \min }, S_{\mathrm{i}, \min }\right),
$$

де 30,5 - середня кількість днів у місяці;

$F(\ldots)$ - функція нормального розподілу;

$X_{\text {min }}$ - мінімальне розрахункове значення температури;

$M_{i, \min }$ - середнє значення мінімальної температури в і-тому місяці року;

$S_{i, \min }$ - стандарт мінімальної температури в і-тому місяці року.

Аналогічно визначається тривалість $T_{\max }$ перебування температури вище максимального розрахункового значення $X_{\max }$ :

$$
T_{\max }=30,5 \times T \times \sum_{i=1}^{12}\left[1-F\left(X_{\max }, M_{\mathrm{i}, \max }, S_{\mathrm{i}, \max }\right)\right],
$$

де $X_{\max }$ - максимальне розрахункове значення температури;

$M_{i, \max }$ - середнє значення максимальної температури в $i$-тому місяці;

$S_{i, \max }$ - стандарт максимальної температури в $i$-тому місяці року.

Вважаючи, що вихід за межі розрахункових значень допускається протягом однієї доби за строк служби, прирівнюємо вирази (1) і (2) до одиниці. Чисельний розв'язок отриманих рівнянь відносно $X_{\min }$ та $X_{\max }$ дає мінімальне та максимальне розрахункове значення температури грунту чи повітря. Результати визначення розрахункових значень температури грунту на метеостанції м. Ново-Миргород для різних глибин і періодів повторюваності $T=20 \ldots 200$ років наведені в табл. 1 .

3 таблиці видно, що розрахункові значення температури грунту змінюються 3 глибиною та періодом повторюваності. Дані таблиці вказують на незначну залежність розрахункових значень температури грунту від періоду повторюваності. Починаючи 3 глибини 0,2 м, мінімальні розрахункові значення для $T=20$ років і $T=200$ років відрізняються не більше, ніж на $1,5^{\circ} \mathrm{C}$, а максимальні - на $0,9^{\circ} \mathrm{C}$. Це дозволяє у подальшому прийняти єдині розрахункові значення температури грунту для періоду повторюваності $\mathrm{T}=100$ років, близьким до найбільшого рекомендованого нормами [2] терміну експлуатації будівель та споруд $T_{e f}=120$ років. Поширення прийнятих розрахункових 
значень на усі інші строки служби будівель та споруд дасть незначні похибки, переважно в запас надійності.

Таблиця 1

Розрахункові значення температури грунту на метеостанції м. Ново-Миргород Кіровоградської області

\begin{tabular}{|c|c|c|c|c|c|c|c|c|c|c|}
\hline \multirow[t]{2}{*}{$\begin{array}{c}\text { Глиби- } \\
\text { на, м }\end{array}$} & \multicolumn{5}{|c|}{$\begin{array}{c}\text { Мінімальні розрахункові } \\
\text { значення } X_{\min } \text { при періодах } \\
\text { повторюваності } T,{ }^{\circ} \mathrm{C}\end{array}$} & \multicolumn{5}{|c|}{$\begin{array}{c}\text { Максимальні розрахункові } \\
\text { значення } X_{\max } \text { при періодах } \\
\text { повторюваності } T,{ }^{\circ} \mathrm{C}\end{array}$} \\
\hline & 20 & 50 & 100 & 150 & 200 & 20 & 50 & 100 & 150 & 200 \\
\hline DBI & 6,7 & 10 & & & & & & & & \\
\hline & & & & & & & & & & \\
\hline & & & & & & , & & & & \\
\hline & & & & & & 0 & & & & 24, \\
\hline & & & & & -4 & 20,8 & & & & 21, \\
\hline &, 2 & -0 & & & -1 & 18, & & 18 & & 18, \\
\hline & & & & & & 16,3 & & & & 10,6 \\
\hline &,+ 1 & & & & & 14,5 & 14,6 & 14,7 & 14,8 & 14,8 \\
\hline 3,2 & 6,1 & 6,0 & 5,9 & 5,9 & 5,8 & 12,9 & 13,0 & 13,0 & 13,1 & 13,1 \\
\hline
\end{tabular}

Залежності мінімальних та максимальних розрахункових температур грунту від глибини наведені на рис. 4.3 рис. 4 і табл. 1 видно, що розрахункові значення мінімальних і максимальних (холодної та теплої) температур на поверхні грунту можуть відрізнятися на $72 \ldots 77^{\circ} \mathrm{C}$. Настільки значні коливання температури поверхні грунту обумовлені нагріванням від сонячної радіації, яка робить максимальну температуру поверхні грунту значно вищою, ніж температура повітря влітку.

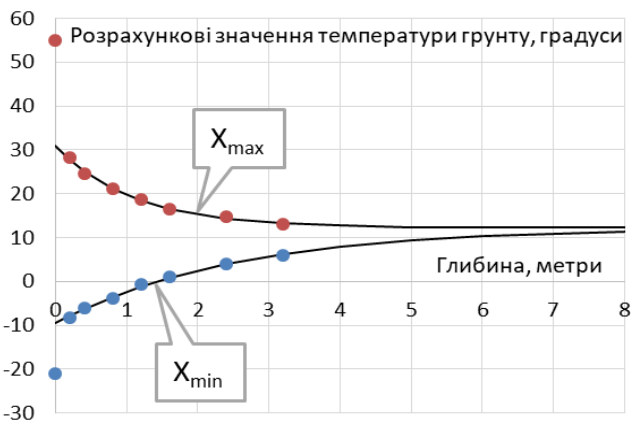

Рис. 4. Залежності розрахункових значень температури грунту від глибини
Значні

розрахункових температури від поверхні грунту до глибини $0,2 \mathrm{~m}$ пояснюються тим, що грунт діє як теплоізоляція і сильно нівелює зміни температури на поверхні. 3 ростом глибини розрахункові значення мінімальної й максимальної температури зближуються, і на глибині $3,2 \mathrm{м}$ різниця між ними складає $7 \ldots 12^{\circ} \mathrm{C}$. 
Залежності прийнятих розрахункових значень температури грунту від глибини (починаючи з 0,2 м і глибше) описані аналітичними виразами

$$
\begin{aligned}
& t_{c}=a_{c} \exp \left(b_{c} h\right)+t_{0}=-21,8 \exp (-0,40 h)+12,2 ; \\
& t_{w}=a_{w} \exp \left(b_{w} h\right)+t_{0}=18,7 \exp (-0,92 h)+12,2,
\end{aligned}
$$

де $t_{c}$ i $t_{w}$ - розрахункові значення мінімальної (холодної) та максимальної (теплої) температури грунту на глибині $h, \mathrm{~m}$;

$a_{c}, a_{w}, b_{c}, b_{w}, t_{0}-$ коефіцієнти, встановлені методом найменших квадратів.

Коефіцієнти формул (3) і (4) визначені за методом найменших квадратів [3] шляхом мінімізації суми квадратів відхилень теоретичних значень (3), (4) від фактичних даних 3 урахуванням розрахункових температур грунту на глибині 0,2 м і більше. Урахування в обох формулах спільного коефіцієнта $t_{0}$ забезпечує асимптотичне наближення мінімальних і максимальних розрахункових значень температури грунту до одного й того ж значення температури стабілізації $t_{0}$ на великій глибині.

На рис. 4 показані результати апроксимації даних метеостанції м. Ново-Миргород кривими (3), (4). 3 ростом глибини мінімальні та максимальні розрахункові значення (3) і (4) наближаються до температури $+12,2^{\circ} \mathrm{C}$. На глибині $h=8$ м різниця між ними становить $0,9^{\circ} \mathrm{C}$, а на глибині $13 \mathrm{M}-0,1^{\circ} \mathrm{C}$. Це дозволяє вважати, що на глибині понад $8 \mathrm{M}$ температура грунту залишається практично незмінною протягом усього року.

Розрахункові значення температури грунту на метеостанціях України. Розроблена методика дозволила встановити розрахункові значення температури грунту для усіх 11 обраних метеостанцій, а також проаналізувати та узагальнити зміни температури грунту на різних глибинах по території України. За даними обраних метеостанцій обчислені розрахункові значення мінімальної та максимальної температури повітря, температури на поверхні грунту, а також на глибинах $0,2 \ldots 3,2$ м для періодів повторюваності від 20 до 200 років. Залежності розрахункових значень температури грунту від глибини описані аналітичними виразами (3) i (4), коефіцієнти яких наведені в табл. 2. В передостанньому стовпчику табл. 2 наведені температури стабілізації $t_{0}$, а в останньому - значення глибини стабілізації $h_{0}$, на якій різниця мінімальної та максимальної розрахункової температури не перевищує $1^{\circ} \mathrm{C}$.

3 таблиці видно, що температура грунту на глибині асимптотично наближається до величин $t_{0}=+12 \ldots+18^{\circ} \mathrm{C}$. Середня температура стабілізації дорівнює $+14,5^{\circ} \mathrm{C}$, що загалом відповідає температурі повітря в глибоких печерах. Глибина стабілізації температури грунту в основному змінюється в межах $h_{0}=8 \ldots 13 \mathrm{\text {i }}$ в середньому дорівнює $h_{0}=10 \mathrm{~m}$. 
Виняток складають метеостанції м. Новоград-Волинський та м. Чернігів, де температура грунту стабілізується на глибині близько 18 м.

Таблиця 2

Коефіцієнти формул (1) і (2) та глибина стабілізації температури грунту для метеостанцій України

\begin{tabular}{|l|c|c|c|c|c|c|c|}
\hline Метеостанції України & $a_{c}$ & $b_{c}$ & $a_{w}$, & $b_{w}$ & $t_{0},{ }^{\circ} \mathrm{C}$ & $h_{0}, \mathrm{M}$ & $h_{n}, \mathrm{M}$ \\
\hline Артемівськ & $-21,0$ & $-0,35$ & 19,8 & $-1,20$ & 13,8 & 8,8 & 1,2 \\
\hline Бережани & $-19,4$ & $-0,28$ & 16,4 & $-1,05$ & 13,0 & 10,6 & 1,4 \\
\hline Керч & $-19,1$ & $-0,27$ & 18,6 & $-0,89$ & 16,2 & 10,9 & 0,6 \\
\hline Ковель & $-25,4$ & $-0,25$ & 18,5 & $-2,27$ & 18,5 & 12,7 & 1,3 \\
\hline Луганськ & $-24,3$ & $-0,40$ & 23,7 & $-0,90$ & 14,1 & 8,0 & 1,4 \\
\hline Новоград-Волинський & $-15,1$ & $-0,14$ & 19,5 & $-1,36$ & 13,0 & 18,9 & 1,1 \\
\hline Ново-Миргород & $-21,8$ & $-0,40$ & 18,7 & $-0,92$ & 12,2 & 7,7 & 1,4 \\
\hline Одеса & $-22,1$ & $-0,27$ & 16,3 & $-0,66$ & 15,6 & 11,6 & 1,3 \\
\hline Полтава & $-23,5$ & $-0,36$ & 18,6 & $-0,98$ & 13,2 & 8,7 & 1,6 \\
\hline Херсон & $-23,4$ & $-0,24$ & 17,6 & $-1,09$ & 17,2 & 12,9 & 1,3 \\
\hline Чернігів & $-15,7$ & $-0,16$ & 14,9 & $-0,79$ & 13,1 & 17,5 & 1,2 \\
\hline
\end{tabular}

Отримані результати не вказують на наявність виражених закономірностей територіальної мінливості розрахункових значень температури грунту. Можливість територіального районування слід перевірити 3 використанням даних більшої кількості метеостанцій. При цьому потрібно врахувати, що здійсненню територіального районування розрахункових значень температури грунту може перешкодити істотний вплив теплових характеристик різних грунтів, характер рослинного покриву, різна експозиція схилів та інші невраховані фактори.

Дані табл. 2 дозволяють визначати мінімальні та максимальні розрахункові значення температури грунту на заданій глибині за формулами (3) та (4). Мінімальні розрахункові значення необхідні для виконання теплотехнічних розрахунків при проектуванні підземних приміщень. Температурні перепади між мінімальними та максимальними розрахунковими значеннями можуть використовуватися для оцінювання силових впливів температури грунту на підземні несучі конструкції, що контактують 3 грунтом.

У якості прикладу визначимо глибину, на якій температура грунту не опускається нижче $t_{c}=0^{\circ} \mathrm{C}$. Розв'язок рівняння (4) відносно $h$ при значенні $t_{c}=0^{\circ} \mathrm{C}$ має вигляд:

$$
h=\frac{\ln \left(-t_{0} / a_{c}\right)}{b_{c}} .
$$


Результати обчислень за формулою (5) наведені в останньому стовпчику табл. 2. Ці дані можна вважати прогнозними значеннями глибини промерзання грунту в районі досліджених метеостанцій. Вони $є$ дещо завищеними, оскільки відповідають періоду повторюваності 100 років. Окрім того унаслідок мінералізації грунтових вод їх замерзання може відбуватися при температурах, нижчих від $0^{\circ} \mathrm{C}$, тобто на дещо меншій глибині.

\section{Висновки та перспективи подальших досліджень}

1. За результатами статистичного аналізу результатів метеорологічних спостережень на метеостанціях України підтверджені закономірності зміни середніх температур грунту на різних глибинах. Показано, що стандарти температури грунту не мають вираженої сезонної мінливості, але систематично зменшуються з ростом глибини.

2. Розроблена методика визначення мінімальних та максимальних розрахункових значень температури грунту 3 урахуванням заданого періоду повторюваності. Рекомендовано в якості розрахункових значень температури грунту 3 незначним запасом прийняти значення, що відповідають періоду повторюваності 100 років.

3. Залежності мінімальних і максимальних розрахункових значень температури грунту від глибини для 11-ти метеостанцій України описані аналітичними виразами. За зближенням мінімальних i максимальних розрахункових значень температури встановлено, що на глибині $8 \ldots 13$ м температура грунту стабілізується на рівні $+12 \ldots+18^{\circ} \mathrm{C}$.

4. Отримані результати можуть використовуватися при виконанні теплотехнічних розрахунків заглиблених приміщень та при оцінюванні силового впливу температури на підземні конструкції.

\section{References}

1. DSTU-N B V.1.1-27:2010 Zaxy`st vid nebezpechny`x geologichny`x procesiv, shkidly`vy`x ekspluatacijny`x vply`viv, vid pozhezhi. Budivel`na klimatologiya. - K., 2010. $-101 \mathrm{~s}$.

2. DBN V.1.2-2:2006. Sy`stema zabezpechennya nadijnosti ta bezpeky` budivel 'ny`x ob'yektiv. Navantazhennya i vply`vy'. Normy` proektuvannya. K.: Minbud Ukrayiny", 2007.

3. DBN V.2.6-31:2016: Teplova izolyaciya budivel - K.: Ministerstvo budivny`cztva Ukrayiny', 2016. - $31 \mathrm{~s}$.

4. Nagruzky 'y'vozdejstvy`ya na zdany`ya y` sooruzheny`ya / A.V. Perel'muter, V.N. Gordeev, A.Y`. Lantux-Lashhenko, A.V.Maxy`n`ko, V.A. Pashy`nsky`j, S.F. Py`chugy`n / Pod obshhej red. A.V. Perel'mutera. - 4-e y`zd., pererab. - M.: Y'zdatel'stvo SKAD SOFT, y`zdatel`stvo ASV, y`zdatel`stvo DShhMK Press, 2014. $596 \mathrm{~s}$.

5. Nastanova gidrometeorologichny`m stanciyam i postam. Vy`pusk 3. Chasty`na 1. Meteorologichni sposterezhennya na stanciyax. : Vy`dannya oficijne - K.: Derzhavna gidrometeorologichna sluzhba, 2011. $-280 \mathrm{~s}$. 
6. Kinash R.I. Temperaturny`j rezhy`m povitrya i g`runtu v Ukrayini / R.I. Kinash, O.M. Burnayev. - L`viv: Vy`davny`cztvo naukovo-texnichnoyi literatury`, 2001. $-800 \mathrm{c}$.

7. Zatula V.I., Ty`tarenko L.M. Rezhy`m temperatury` g`runtu na gly`by`nax. / Cherkas`ky`j nacional`ny`j universy`tet imeni Bogdana Xmel`ny`cz`kogo, 2009. StudFiles. - [Elektronny`j resurs] Rezhy`m dostupu: https://studfile.net/preview/7455426/page:27/

8. Shven` N.I., My`tny`k T.G., Ga`’perina T.O. Analiz bagatorichny`x tendencij dy`namiky` temperatury` g`runtu na gly`by`nax pid pry`rodny`m pokry`vom. Gidrologiya, gidroximiya i gidroekologiya. 2017. \# 3 (46), s. 86-95

9. Ventcel` E.S. Teory`ya veroyatnostej: Uchebny`k dlya vuzov. 10-e y`zd., ster. - M.: Vыsshaya shkola, 2006. - 575 s.

10. DBN V.1.2-14-2018. Sy`stema zabezpechennya nadijnosti ta bezpeky budivel`ny`x ob'yektiv. Zagal`ni pry`ncy`py` zabezpechennya nadijnosti ta konstrukty`vnoyi bezpeky` budivel', sporud, budivel'ny`x konstrukcij ta osnov. - K.: Minregionbud Ukrayiny`, 2018.

\section{Список використаної літератури}

1. ДСТУ-Н Б В.1.1-27:2010 Захист від небезпечних геологічних процесів, шкідливих експлуатаційних впливів, від пожежі. Будівельна кліматологія. - К., 2010. - $101 \mathrm{c}$.

2. ДБН В.1.2-2:2006. Система забезпечення надійності та безпеки будівельних об'єктів. Навантаження і впливи. Норми проектування. К.: Мінбуд України, 2007.

3. ДБН В.2.6-31:2016: Теплова ізоляція будівель - К.: Міністерство будівництва України, 2016. - 31 с.

4. Нагрузки и воздействия на здания и сооружения / А.В. Перельмутер, В.Н. Гордеев, А.И. Лантух-Лащенко, А.В.Махинько, В.А. Пашинский, С.Ф. Пичугин / Под общей ред. А.В. Перельмутера. - 4-е изд., перераб. - М.: Издательство СКАД СОФТ, издательство АСВ, издательство ДЩМК Пресс, 2014. - 596 с.

5. Настанова гідрометеорологічним станціям і постам. Випуск 3. Частина 1. Метеорологічні спостереження на станціях. : Видання офіційне - К.: Державна гідрометеорологічна служба, 2011. - 280 с.

6. Кінаш P.I. Температурний режим повітря і грунту в Україні / P.I. Кінаш, О.М. Бурнаєв. - Львів: Видавництво науково-технічної літератури, 2001. - 800 с.

7. Затула В.І., Титаренко Л.М. Режим температури грунту на глибинах. / Черкаський національний університет імені Богдана Хмельницького, 2009. StudFiles. - [Електронний pecypc] Режим доступу: https://studfile.net/preview/7455426/page:27/

8. Швень Н.І., Митник Т.Г., Гальперіна Т.О. Аналіз багаторічних тенденцій динаміки температури грунту на глибинах під природним покривом. Гідрологія, гідрохімія і гідроекологія. 2017. № 3 (46), с. 86-95

9. Вентцель Е.С. Теория вероятностей: Учебник для вузов. 10-е изд., стер. М.: Высшая школа, 2006. - 575 с.

10. ДБН В.1.2-14-2018. Система забезпечення надійності та безпеки будівельних об'єктів. Загальні принципи забезпечення надійності та конструктивної безпеки будівель, споруд, будівельних конструкцій та основ. - К.: Мінрегіонбуд України, 2018. 